\title{
An analysis of online privacy concerns of teacher candidates
}

\author{
Dr. Agâh Tuğrul KORUCU* \\ Department of Computer Education and Instructional Technology, Ahmet Kelesoglu Faculty \\ of Education, Necmettin Erbakan University, Konya / TURKEY
}

\author{
Şerife GÜRKEZ \\ Department of Computer Education and Instructional Technology, Ahmet Kelesoglu Faculty \\ of Education, Necmettin Erbakan University, Konya / TURKEY
}

\begin{tabular}{ll}
\hline \hline Article history & Examining the online privacy concerns of our prospective teachers who \\
Received: & will raise our future generations is important in terms of determining and \\
& increasing the awareness levels of prospective teachers of the digital \\
Received in revised form: & world and for the development of a conscious generation having this \\
14.06 .2019 & awareness while raising students. The definition of cyber space or virtual \\
& environments has further expanded; digital business applications, online \\
Accepted: & services, online training systems, e-commerce sites, social media sites, \\
and surely multiplayer video games have also been included in the & definition. The definition of these digital spaces as virtual spaces creates \\
Key words: & questions as to how individuals exist in these places and how they travel \\
\hline online privacy, teacher & in these places. This study, whose aim is to analyze online confidentiality \\
candidates, anxiety, Internet. & concerns of prospective teachers in terms of various variables, consists of \\
& 92 teacher candidates who were studying in Necmettin Erbakan \\
& University of Konya in 2018-2019 academic year. In this study, where \\
& quantitative research was adopted, surveying model was used as a \\
& research method. The data collection tool was "The Online Privacy \\
& Concern Scale (OPCS)" developed. Descriptive statistics, Independent \\
& samples t-test and one-way analysis of variance were used during the \\
& analysis. It is found out that online privacy concerns of teacher candidates \\
& differ significantly in terms of mobile device usage times and classes. \\
& However there was no significant difference in online privacy concerns in \\
& terms of information and communication technologies usage levels, \\
& weekly Internet usage times, gender, department, age and mobile usage \\
& level.
\end{tabular}

\section{Introduction}

The well-known science-fiction writer William Gibson used the term 'cyber space' for the first time in his 1984 Neuromancer novel, to describe the digital spaces formed by online communication technologies (Benedikt, 1991; Şengün, 2014). The definition of cyber space or virtual environments has further expanded; digital business applications, online services, online training systems, e-commerce sites, social media sites, and without doubt multiplayer video games have also been included in the definition. The definition of these digital spaces 
as virtual spaces creates questions as to how individuals exist in these places and how they travel in these places (Şengün, 2014).

According to Çelikoğlu (2008), religious and political views are also classified as intimate. In the societies that experienced modernity body, various regions of the body, sexuality, family, romantic relations, household etc. and a variety of commodities connected to them. In fact many things that people do not want to share with others or share in a controlled way can enter the sphere of privacy. Yet what enters the domain of privacy can be listed as the person, gender, age, class position, culture, social environment, social status, and hence there will be more than one definition of privacy (Şener, 2013). The concept of privacy, first dealt with by Warren and Brandies (1890) in the 19th century, was defined as the right to be left alone. Sites with social networking and content sharing constitute important online activities on the Internet (Raad \& Chbeir, 2013). In all these relations, social media is a tool that brings the relationship to a point of binding, reinforcing and sometimes breaking we are seen as. At a time when social networks become places of daily socialization, the ways in which intimate relationships are experienced and shaped according to the wishes and dynamics of the age, the privacy management of social media users becomes a part of virtual identity strategies (Şener, 2013), and the impact of social media on people's private life and user behavior have been questioned (Taşdelen \& Çataldaş, 2017). The widespread use of the Internet and social media accounts in the society has opened up the public's perception of privacy (Turan, 2015). In social media usage, it is observed that women pay more attention to privacy than male users. (De Wolf, Willaert \& Pierson, 2014; Hoy \& Milne, 2010; Külcü \& Henkoğlu, 2014, Litt, 2013).Therefore today's scientific studies focus on the privacy of the Internet, and in a significant majority of the studies, privacy is addressed in the axis of concern for the violation of the privacy of the individual (Y1ldırım, 2016). Taddicken (2013) in his research, studied privacy concerns on the Internet self-disclosure behavior.

Most people are aware that their personal information is collected and disseminated on the Internet without their consent, and that they have no control over this information. However, users see this as a necessity; an inevitable part of modern life in order to be able to receive some services as desired (Karlıdağ, 2014). Therefore, the data belonging to confidential information of the users are shared with the third parties. It is vital that this information obtained should not be used or distributed without the consent of the user. However, users themselves have a fundamental and important responsibility for the protection of their confidentiality (Külcü \& Henkoğlu, 2015).

In Turkey, our dependence on IT infrastructures and the Internet is increasing and the risks on cyberspace are on the increase (Hekim, 2013). Notwithstanding, many people are not aware of the importance of risks. If any piece of information is known by the third parties, this information is not confidential anymore and this may cause anxiety for the individual. The information found on the Internet can quickly spread to third parties. This spread occurs in fact by attacks to the system used by the individual mentioned above (Karaaslan, Koç and Eren, 2014).

One of the best ways to determine online privacy is to measure concerns of people about online technologies. The extent to which people expect online risks and the extent to which people are exposed to these risks have been demonstrated by various studies. When the literature is examined, it is seen that the number of studies on privacy anxiety has boosted in recent years. Here are a few examples of these studies in the literature; Aslanyurek (2016) has investigated the Internet and social media users' opinions about online privacy. Accordingly, 
half of the participants believe that the internet and social networking sites provide a reliable communication environment. Non- supervised websites and social networking sites despite the privacy violations experienced continue to exist on the internet and $28 \%$ of the users stated that they will continue. For those who are indecisive the rate is quite high; $42 \%$. For $20 \%$ fake profiles on social networking sites can be used against privacy violations.

This research enables the teacher candidates to raise concerns about online privacy in the digital world. Teachers, who have an integral role in education, contribute to the knowledge of privacy in the digital world. With the emergence of online privacy concerns of prospective teacher candidates who will raise our future generations, they will be more aware of the digital world and guide their students towards developing a conscious generation accordingly. With this research, it is aimed to attract more attention to the online privacy of prospective teachers by drawing attention to privacy and personal privacy issues on the Internet. The answers to the following research questions were sought around this general purpose;

(1) Do teacher candidates' scores on The Online Privacy Concern Scale (OPCS) vary according to gender?

(2) Do teacher candidates' scores on The Online Privacy Concern Scale (OPCS) vary according to the department they study at?

(3) Do teacher candidates' scores on The Online Privacy Concern Scale (OPCS) vary according to their grade?

(4) Do teacher candidates' scores on The Online Privacy Concern Scale (OPCS) vary according to weekly Internet use?

(5) Do teacher candidates' scores on The Online Privacy Concern Scale (OPCS) vary according to age ranges?

(6) Do teacher candidates' scores obtained on The Online Privacy Concern Scale (OPCS) vary according to the experience of using information and communication technology?

(7) Do teacher candidates' scores on The Online Privacy Concern Scale (OPCS) vary according to Internet access?

(8) Do teacher candidates' scores on The Online Privacy Concern Scale (OPCS) vary according to their ability to use mobile devices?

(9) Do teacher candidates' scores on The Online Privacy Concern Scale (OPCS) vary according to the duration of using mobile devices?

\section{Method}

\section{Method of Research}

In this study, where quantitative research was adopted, survey model was used as the research method. Research on which the relevant characteristics are determined generally focused on larger samples compared to other studies (Metin, 2014).

\section{Data collection tool}

In this study, data were collected by the demographic data form developed by the researchers and the Online Privacy Concerns Scale (OPCS) developed by Alakurt (2017).

Online Privacy Concerns Scale (OPCS); There are no graded items in the 5-point Likert-type (1-ever ..... 5-very frequent) scale. The Cronbach alpha internal consistency coefficient for the whole scale was calculated as, 87 . The high score of the scale indicates that online privacy 
concerns are high.

In the demographic data collection tool; the participants' demographic data were collected in relation to gender, age ranges, class levels, weekly Internet usage, level of use of ICT, mobile device ownership, mobile device usage levels.

\section{Working group}

The study was consisted of 92 teacher candidates from the Faculty of Education of Necmettin Erbakan University, Ahmet Kelesoglu, Konya, Turkey. Sixty-six of them are female and twenty-six of them are male. Demographic information of prospective teachers is given in Table 1.

Table 1. Demographic information of the participants

\begin{tabular}{|c|c|c|c|}
\hline Variables & Levels & $\mathbf{N}$ & $\%$ \\
\hline \multirow{2}{*}{ Gender } & female & 66 & 71,7 \\
\hline & male & 26 & 28,3 \\
\hline \multirow{2}{*}{ Grade } & 1. grade & 55 & 59,8 \\
\hline & 3. grade & 37 & 40,2 \\
\hline \multirow{2}{*}{ Age } & $17-21$ & 67 & 72,8 \\
\hline & $21-30$ & 25 & 27,2 \\
\hline \multirow{2}{*}{ Department } & CEIT(computer teaching) & 36 & 39,1 \\
\hline & other teaching departments & 56 & 60,9 \\
\hline \multirow{3}{*}{ ICT Usage Time } & No Experience & 18 & 19,6 \\
\hline & 1-5 Year & 37 & 40,2 \\
\hline & More than 6 years & 37 & 40,2 \\
\hline \multirow{2}{*}{ Is there Internet? } & Yes & 88 & 95,7 \\
\hline & No & 4 & 4,3 \\
\hline \multirow{4}{*}{ Weekly Internet Usage } & 0-3 Hours & 12 & 13,0 \\
\hline & 3-6 Hours & 9 & 9,8 \\
\hline & 6-9 Hours & 19 & 20,7 \\
\hline & More than 9 hours & 52 & 56,5 \\
\hline \multirow{3}{*}{ Mobile Competence } & medium & 30 & 32,6 \\
\hline & Sufficient & 51 & 55,4 \\
\hline & Very Sufficient & 11 & 12,0 \\
\hline \multirow{3}{*}{$\begin{array}{l}\text { Since When have Mobile Devices } \\
\text { been used? }\end{array}$} & 0-2 Year & 9 & 9,8 \\
\hline & 2-4 Year & 20 & 21,7 \\
\hline & 4-6 Year & 63 & 68,5 \\
\hline \multirow{2}{*}{$\begin{array}{l}\text { Through Which Device Do You } \\
\text { Access the Internet? }\end{array}$} & Computer & 7 & 7,6 \\
\hline & Mobile & 85 & 92,4 \\
\hline \multicolumn{2}{|l|}{ TOTAL } & 92 & 100 \\
\hline
\end{tabular}

When Table 1 is examined, it was found out that the number of female participants $(71.7 \%)$ was higher than the male ones (28.3), and the number of 1 st grade students $(59.8 \%)$ was higher than the 3rd grade students $(40.2 \%)$ and that the age range was 17-21 (72.8\%) forming the majority. Participants were studying in different departments and stated that they had been using ICT technologies for $1-5$ years $(40,2 \%)$ and more than 6 years $(40,2 \%)$. Almost all of these participants had Internet access $(95,7 \%)$, and their weekly Internet use was mostly over 9 hours $(56,5 \%) .55 .4 \%$ of the participants declared themselves as self-sufficient in mobile use, $32.6 \%$ of those considered themselves to be sufficiently moderate. Almost all of the participants were accessing the Internet from mobile $(92,4 \%)$, and $68.5 \%$ of these participants stated that they had had mobile devices for 4-6 years. 


\section{Data Analysis}

For the statistical analysis of the data transferred to the computer environment, SPSS statistical package programs were used. In addition to descriptive statistical analyses, parametric tests were used in the tests performed with the collected data because of the normal distribution of the data was both $\mathrm{n}=92$. For the analysis of demographic information, percentage and frequency, arithmetic mean and standard deviation; for general average scores of teacher candidates, class level, type of school, independent sample $t$ test; for online privacy perceptions according to gender, one way ANOVA test were resorted to. To interpret the related data, 3 sets of evaluation criteria-low, medium and high-were determined and the evaluation intervals in Table 2 were used. In the analysis of the data, .05 was taken as the significance level and the data were analyzed by SPSS 22 program.

\section{Findings} headings.

The findings obtained in line with the sub-objectives of the research are given as

\section{Online Privacy Concern Situations of Teacher Candidates}

Within the scope of the study, teacher candidates' online perception of privacy perception was investigated.

\section{The Situations of Teacher Candidates' Online Confidence Concerns in Terms of Some Variables}

For the analysis of the online privacy concern levels of teacher candidates in terms of some variables was examined.

Table 2. An analysis of online privacy concerns according to gender

\begin{tabular}{lllllll}
\hline Gender & $\underline{\mathbf{n}}$ & $\overline{\mathbf{X}}$ & Ss & sd & $\mathbf{t}$ & $\mathbf{p}$ \\
\hline Female & 66 & 43,23 & 11,222 & 44,560 & 1,257 & 0,215 \\
Male & 26 & 39,88 & 11,584 & & & \\
\hline
\end{tabular}

$* \mathrm{p}>.05$

When Table 2 is examined, it is witnessed that the average of female teacher candidates is $\bar{X}=$ 43,23 and the average of male teacher candidates is $\bar{X}=39,88$. The independent sample $t$ test to determine the difference between the groups demonstrated no significant difference between the groups $[\mathrm{t}(44,560)=.257, \mathrm{p}>.05]$.

Table 3. An analysis of online privacy concerns according to the grade

\begin{tabular}{lllllll}
\hline Grade & $\underline{\mathbf{n}}$ & $\overline{\mathbf{X}}$ & Ss & sd & $\mathbf{t}$ & $\mathbf{p}$ \\
\hline 1.grade & 55 & 44,29 & 11,135 & 90 & 2,106 & 0,038 \\
3.grade & 37 & 39,30 & 11,182 & & & \\
\hline
\end{tabular}

$* \mathrm{p}>.05$

When Table 3 is examined, the average of the teacher candidates studying in the first year is found out as $\bar{X}=44.29$ and the average of the teacher candidates studying in the third grade is seen as $\bar{X}=39.30$. The independent sample t-test demonstrated a significant difference between the groups. 
Table 4. An analysis of online privacy concerns according to age

\begin{tabular}{lllllll}
\hline Age & $\underline{\mathbf{n}}$ & $\overline{\mathbf{X}}$ & Ss & sd & $\mathbf{t}$ & $\mathbf{p}$ \\
\hline $\mathbf{1 7 - 2 1}$ & 67 & 42,69 & 11,087 & 39,593 &, 531 & 0,598 \\
$\mathbf{2 1 - 3 0}$ & 25 & 41,20 & 12,241 & & & \\
\hline
\end{tabular}

$* \mathrm{p}>.05$

When Table 4 is examined, it is seen that the average of the teacher candidates whose age is between 17-21 years is $\bar{X}=42.69$ and the average of the teacher candidates with the age of 2130 is $\bar{X}=41.20$. The independent sample $t$ test to determine the difference between the groups showed no significant difference between the groups $[\mathrm{t}(39,593)=.531, \mathrm{p}>.05]$.

Table 5. An analysis of online privacy concerns according to the department

\begin{tabular}{lllllll}
\hline Department & $\underline{\mathbf{n}}$ & $\overline{\mathbf{X}}$ & Ss & sd & $\mathbf{t}$ & $\mathbf{p}$ \\
\hline CEIT & 36 & 39,69 & 11,073 & 76,047 & 1,781 & 0,079 \\
Other & 56 & 43,95 & 11,330 & & & \\
\hline
\end{tabular}

$* p>.05$

When Table 5 is examined, the average of the teacher candidates who have a CEIT is $\overline{\mathrm{X}}=$ 39.69 and the average of the teacher candidates studying in the other departments is $\bar{X}=$ 43.95. The independent sample t test to determine the difference between the groups showed no significant difference between the groups $[t(76,047)=.781, \mathrm{p}>.05]$.

Table 6. An analysis of online privacy concerns according to "Where is your residence ?" question

\begin{tabular}{lllllll} 
Place of Residence & $\underline{\mathbf{n}}$ & $\overline{\mathbf{X}}$ & Ss & sd & $\mathbf{t}$ & $\mathbf{p}$ \\
\hline Home & 44 & 43,18 & 11,223 & 89,679 &, 726 & 0,470 \\
Dorm & 48 & 41,46 & 11,544 & & & \\
\hline
\end{tabular}

$* p>.05$

When Table 7 is examined, it is seen that the average of the teacher candidates who stated home as the place of residence is $\bar{X}=43.18$ and the average of the teacher candidates who expressed dorm is $\bar{X}=41.46$. The independent sample t-test to determine the difference between the groups demonstrates that there was no difference between the groups $[\mathrm{t}(89,679)=.726, \mathrm{p}>.05]$.

Table 7. ANOVA results of online privacy concern scale scores by ICT usage time

\begin{tabular}{lllllll}
\hline & KT & Sd & KO & $\boldsymbol{F}$ & $\boldsymbol{p}$. & $\begin{array}{l}\text { Significant } \\
\text { difference }\end{array}$ \\
\hline Between Groups & 34,172 & 2 & 17,086 &, 130 &, 878 & ----- \\
In groups & 11714,480 & 89 & 131,623 & & & \\
\hline Total & 11748,652 & 91 & & & & \\
\hline
\end{tabular}

The teacher candidates' online privacy concern descriptive statistics are given in Table 7a and the ANOVA results in terms of ICT usage levels are given in Table 7. 
Table 7a. Descriptive statistics of scale scores

\begin{tabular}{llll}
\hline ICT Usage time & $\underline{\mathbf{n}}$ & $\overline{\mathbf{X}}$ & Ss \\
\hline No Experience & 18 & 41,11 & 10,180 \\
1-5 Year & 37 & 42,35 & 11,109 \\
More than 6 years & 37 & 42,78 & 12,372 \\
\hline Total & 92 & 42,28 & 11,362 \\
\hline
\end{tabular}

The results show that there is no significant difference between teacher candidates' online privacy concerns and ICT usage period $[\mathrm{F}(2,89)=.130, \mathrm{p}<.05]$. In other words, the concerns of prospective teachers do not change significantly according to the ICT usage period.

Table 8. ANOVA results online privacy concern scale scores according to weekly internet usage periods

\begin{tabular}{lllllll}
\hline & $\boldsymbol{K}$ & $\boldsymbol{S} \boldsymbol{d}$ & $\boldsymbol{K O}$ & $\boldsymbol{F}$ & $\boldsymbol{p}$. & $\begin{array}{l}\text { Significant } \\
\text { difference }\end{array}$ \\
\hline Between Groups & 515,729 & 3 & 171,910 & 1,347 &, 264 & ---- \\
In groups & 11232,923 & 88 & 127,647 & & & \\
\hline Total & 11748,652 & 91 & & & & \\
\hline
\end{tabular}

The online privacy concern descriptive statistics of the teacher candidates are given in Table $8 \mathrm{a}$ and the ANOVA results according to the weekly Internet usage periods are given in Table 8.

Table8a. Descriptive statistics of scale scores

\begin{tabular}{llll}
\hline Weekly Internet Usage & $\underline{\mathbf{n}}$ & $\overline{\mathbf{x}}$ & Ss \\
\hline 0-3 Hour & 12 & 48,17 & 8,747 \\
3-6 Hour & 9 & 42,00 & 13,105 \\
6-9 Hour & 19 & 42,47 & 11,433 \\
More than 9 & 52 & 40,90 & 11,431 \\
\hline Total & 92 & 42,28 & 11,362 \\
\hline
\end{tabular}

The results of the analysis show that there is no significant difference between teacher candidates' online privacy concerns and weekly Internet usage $[\mathrm{F}(3,88)=.347, \mathrm{p}<.05]$. In other words, the concerns of prospective teachers do not change significantly in terms of weekly Internet usage.

Table 9. ANOVA results of online privacy concern scale scores according to competence level of using mobile devices

\begin{tabular}{llllllc}
\hline & $\boldsymbol{K} \boldsymbol{T}$ & $\boldsymbol{S d}$ & $\boldsymbol{K O}$ & $\boldsymbol{F}$ & $\boldsymbol{p}$. & $\begin{array}{l}\text { Significant } \\
\text { difference }\end{array}$ \\
\hline Between Groups & 60,698 & 2 & 30,349 &, 231 &, 794 & ---- \\
In groups & 11687,954 & 89 & 131,325 & & & \\
\hline Total & 11748,652 & 91 & & & & \\
\hline
\end{tabular}

The online privacy concern descriptive statistics of the teacher candidates are given in Table $9 \mathrm{a}$, and the results of ANOVA according to the level of mobile device usage are given in Table 9. 
Table9a. Descriptive statistics of scale scores

\begin{tabular}{llll}
\hline Level of Qualification for Mobile Device Usage & $\underline{\mathbf{n}}$ & $\overline{\mathbf{X}}$ & Ss \\
\hline Medium & 30 & 42,70 & 10,841 \\
Sufficient & 51 & 42,51 & 11,954 \\
Very Sufficient & 11 & 40,09 & 10,653 \\
\hline Total & 92 & 42,28 & 11,362 \\
\hline
\end{tabular}

The results of the analysis show that there is no significant difference between the teacher candidates' online privacy concerns and mobile device usage $[\mathrm{F}(2,89)=.231, \mathrm{p}<.05]$. In other words, the teacher candidates' concerns do not change significantly according to their level of mobile device usage.

Table 10. ANOVA results of online privacy concern scale scores according to duration of mobile device usage

\begin{tabular}{lllllll}
\hline & KT & Sd & KO & $\boldsymbol{F}$ & $\boldsymbol{p}$. & $\begin{array}{l}\text { Significant } \\
\text { difference }\end{array}$ \\
\hline Between Groups & 1223,938 & 2 & 611,969 & 5,175 &, 007 & $\begin{array}{l}\text { 0-2 Year with 2-4 } \\
\text { Year, 4-6 Year }\end{array}$ \\
In groups & 10524,714 & 89 & 118,255 & & & \\
\hline Total & 11748,652 & 91 & & & \\
\hline
\end{tabular}

The online privacy concern descriptive statistics of the teacher candidates are given in Table 10a, and the results of ANOVA according to the mobile device usage duration in Table 10.

Table10a. Descriptive statistics of scale scores

\begin{tabular}{llll}
\hline Mobile Device Usage Duration & $\underline{\mathbf{n}}$ & $\overline{\mathbf{X}}$ & Ss \\
\hline 0-2 Year & 9 & 52,00 & 9,447 \\
2-4 Year & 20 & 44,50 & 11,246 \\
4-6 Year & 63 & 40,19 & 10,931 \\
\hline Total & 92 & 42,28 & 11,362 \\
\hline
\end{tabular}

The results of the analysis show that there is a significant difference between the teacher candidates' online privacy concerns and mobile device usage durations $[\mathrm{F}(2,89)=.175$, $\mathrm{p}<.05]$. That is to say, the teacher candidates' concerns change significantly according to the duration of use of mobile devices. In order to find out the differences between the periods; Tukey HSD test was made use of. According to the results of the Tukey HSD test performed, it could be articulated that there was a significant difference in levels of awareness among the teacher candidates with $0-2$ years $(\bar{X}=52,00)$ and more than 4 years $(\bar{X}=40,19)$ of mobile device usage. According to the results of the Tukey HSD test, it is stated that there was a significant level of awareness among the teacher candidates with $0-2$ years $(\bar{X}=52,00)$ and $2-4$ years $(\bar{X}=44,50)$ of mobile device usage. According to the results of the Tukey HSD test, it is stated that there was no significant level of awareness among the teacher candidates with 2-4 years $(\bar{X}=44,50)$ and more than 4 years $(\bar{X}=40,19)$ of mobile device usage.

\section{Conclusion and Discussion}

In this study, which was conducted with the participation of 92 teacher candidates, analyses were conducted to measure the teacher candidates' online privacy concerns. Descriptive statistics, Independent samples t-test and one-way analysis of variance were used 
during the analysis. Teacher candidates' online privacy concerns vary according to different variables.

The class variable is an important factor in terms of Online Privacy concerns. When Table 3 is examined, it is observed that the average of the teacher candidates studying in the first grade is $\bar{X}=44.29$ and the average of teacher candidates studying in the third grade is $\bar{X}=39.30$. As a result of the Independent sample t test to determine the difference between the groups, it was determined that there was a significant difference between the groups. The difference in the grade levels of the participants may be related to the computer course they had taken at the university. As a result of the analyses, it is observed that there is no significant difference between the students studying in the computer and instructional technology education department and the other students. When results are examined in terms of gender, it is observed that the average of female teacher candidates is $\bar{X}=43.23$ and the average of male teacher candidates is $\bar{X}=39.88 .4$. As a result of the independent sample $t$ test to determine the difference between the groups, no significant difference was observed between the groups. There is no significant difference between teacher candidates' ages. Bergström (2015) found that age affects the risk perception of privacy. Accordingly, it appears that young people have lower risk perceptions due to their greater control over the privacy settings in software and applications.

At the same time, the presence of Internet in the place of residence is not an important factor. There is no significant difference between teacher candidates in terms of online privacy concerns, information and communication technology usage levels and weekly Internet usage durations. As a result of the analyses performed, it is seen that there is a significant difference between the pre-service teachers' online privacy concerns and mobile device use proficiency level and mobile device usage durations. According to the results, it was stated that there was a significant difference between the teacher candidates with mobile device use adequacy period of 0-2 years and 4 years. According to another result of the study, it is stated that there is a significant difference between the candidates who have 0-2 year and 2-4 year of study. Similar to Y1lmaz's (2010) study, it is seen that mobile device usage times affect the perception of privacy. On the other hand, Oktay and Çakır (2012) stated that the attitudes of elementary school teachers towards technology did not change according to the time they spent in front of the computer. Research results show that variables affecting teachers' online privacy anxiety are the level of use of IT devices and the duration of these uses; not the availability of the Internet or what ICT device(s) are used to connect to the Internet. According to the findings of Deep and Yurtdaş's (2017) qualitative study among the participants who did not use Facebook, it was observed that they did not find the structure of the communication and relations on online networks sincere and therefore they attach more importance to face to face communication. It was found that the participants did not experience any anxiety of interaction in their relations and they could easily lead their daily lives. As a result, the following suggestions can be made;

- This study can be re-conducted in terms of different variables with different sample groups.

- In order to examine the concerns of teacher candidates in depth, the data can be collected and supported by qualitative data.

- Teacher candidates may be provided with safety-related training on ICT technologies and Internet use.

- In order to reduce the concerns of teacher candidates, different environments as well as varying scenarios can be presented and solutions can be provided in this regard. 


\section{References}

Alakurt, T. (2017). Adaptation of Online Privacy Concern Scale into Turkish culture. Pegem Journal of Education and Training, 7(4), 611-636.

Aslanyürek, M. (2016). İnternet ve sosyal medya kullanıcılarının internet güvenliği ve çevrimiçi gizlilik ile ilgili kanaatleri ve farkındalıkları [Opinion and awareness of internet and social media users about internet security and online privacy]. Journal of Maltepe University Faculty of Communication, 3(1), 80-106.

Benedikt, M. (1991) Cyberspace: First steps. Cambridge, MA: MIT Press.

Bergström, A. (2015). Online privacy concerns: A Broad approach to understanding the concerns of different groups for different uses. Computers in Human Behavior, 53, 419-426.

Çelikoğlu N. (2008). Mahremiyet [Privacy]. İskenderiye Pub. , İstanbul.

Derin, G. D., \& Yurtdaş, G. T. (2017). Facebook kullanmama tercihinin kendini açma biçimi ve etkileşim kaygısı bağlamında incelenmesi [Investigation of not using Facebook in the context of self-disclosure and interaction anxiety]. Journal of Communication Theory and Research, 1(45), 25-44.

De Wolf, R., Willaert, K. \& Pierson, J. (2014). Managing privacy boundaries to gether: Exploring individual and group privacy management strategies in Facebook. Computers in Human Behavior, 35, 444-454.

Hoy, M. G. \& Milne, G. (2010). Gender differences in privacy-related measures for young adult Facebook users. Journal of Interactive Advertising, 10(2), 28-45.

Karaarslan, E., Eren, M. B., \& Koç, S. (2014). Çevrimiçi Mahremiyet: Teknik ve Hukuksal Durum Incelemesi [Online Privacy: Technical and Legal Situation Review]. Internet Conference Proceedings in Turkey, İzmir.

Külcü, Ö. \& Henkoğlu, T. (2014). Privacy in social networks: An analysis of Facebook. International Journal of Information Management, 34, 761-769.

Külcü, Ö., \& Henkoğlu, T. (2015). Privacy on Social Networks: Facebook Review. Information World, 15(2).

Metin, M. (2014). Kuramdan Uygulamaya Ĕ̆itimde Bilimsel Araştırma Yöntemleri [Scientific Research Methods in Education from Theory to Practice]. Ankara: Pegem Academy Publishing.

Raad, E., \& Chbeir, R. (2013). Privacy in online social networks, In R. Chbeir, \& B. Al Bouna (Eds.), Security and Privacy Preserving in Social Networks (pp. 3-45). Springer,

http://hal.archivesouvertes.fr/docs/00/97/59/98/PDF/Privacy_in_Online_Social_Netw orks .pdf (Erişim: 23-07-2014)

Şener, G. (2013). Sosyal ağlarda mahremiyet ve yeni mahremiyet stratejileri [Privacy and new privacy strategies in social networks]. First National Congress of New Media Studies-Congress Book, 396-405.

Şengün, S. (2014). Dijital avatarlar için semiyotik bir okuma ve avatarların dijital iletişimde belirsizlik azaltma roller [A semiotic reading for digital avatars and the role of avatars in reducing uncertainty in digital communication]. Digital Communication Impact, 34.

Taddicken, M. (2013). The 'Privacy paradox' in the social web: The impact of privacy concerns, individual characteristics, and the perceived social relevance on differentforms of self-disclosure. Journal of Computer-Mediated Communication, 19, 248-273.

Taşdelen, B., \& Çataldaş, İ. (2017). Üniversite öğrencilerinin sosyal medya ve mahremiyete yönelik görüşleri: Lefke Avrupa Üniversitesi örneği [University students' views on 
social media and privacy: European University of Lefke case]. Gumushane University Faculty of Communication Electronic Journal,5(2), 826-844.

Turan, Y. (2015). Iletişim araçlarının mahremiyet algısını şekillendirmedeki rolü [The role of communication tools in shaping the perception of privacy]. Paper presented at the Symposium on Perceptions of Privacy in the Context of Religion, Tradition and Ethics, Samsun.

Warren, S., \& Brandies, L. B. (1890). The right to pivacy. Cambridge, MA: Harward Law Review.

Yabanc1, C , Akça, F , Ulutaş, E . (2018). Çevrimiçi Mahremiyet Kaygısı ve Duygusal Zekâ Arasındaki İlişkinin İncelenmesi [Investigating the Relationship Between Online Privacy Anxiety and Emotional Intelligence]. Connectist: Istanbul University Journal of Communication Sciences, (54), 191-218. Retrieved from http://dergipark.gov.tr/connectist/issue/38035/439127

Yıldırım, F. E. (2016). İnternetten sonra mahremiyet ve bu konudaki çalışmalar üzerine bir inceleme [A review of privacy and studies on the Internet after the Internet.]. Journal of Academic Social Research, 4(33), 568-582.

Yılmaz, R., Karaoğlan-Yılmaz, F. G., Öztürk, H. T., \& Karademir, T. (2017). Examining secondary school students' safe computer and internet usage awareness: An example from Bartın province. Pegem Journal of Education and Training, 7(1), 83-114. http://dx.doi.org/10.14527/pegegog.2017.004 